\title{
The Representations of Nothingness as a Place in Keats's Poetry
}

\author{
Yasir Allawi Al-Jumaili ${ }^{1}$ \\ ${ }^{1}$ Department of English Language, Faculty of Humanities and Social Sciences, Koya University, Kurdistan Region, Iraq
}

\begin{abstract}
This paper addresses the theme of Keats and place in which I mainly focus on the issue of Keats and no place. The existence of 'no place' is a key element in the poetry of John Keats. One of the obvious manifestations of 'no place' is the use of the term 'nothingness' which occupies a particular symbolic significance in his works. The current paper investigates the way Keats views and represents the abstract concept of nothingness. I argue that Keats's poems show evidence that the poet featured nothingness concretely as a place which is characterized by emptiness and void where things fall and disappear forever. The abstract state of 'nothingness' is represented as a hateful and undesired destination that the poet does not want to be placed in. The paper focuses on the representations of nothingness in three selected poems: "Sleep and Poetry", "Endymion" and "When I Have Fears" respectively. In these poems, Keats constructs nothingness as a 'locus' which is associated with negativity and passivity. My paper suggests another possible reading of Keats's poems in relation to the themes of place and space. The study is the first of its kind in regard to the depiction of nothingness in Keats.
\end{abstract}

KEY WORDS: Keats, Mental Process, Nothingness, Place, Space.

\section{INTRODUCTION}

My research project studies the representation of negative mental states in Keats's poetics. I adopt a stylistic method to study the metaphors of mental states from a cognitive perspective. The present paper is a part of this ambitious project. What I would like to do here is to address the theme of Keats and place. I examine the representation of nothingness as a place in selected poems of John Keats. The term "Nothingness" is used by philosophers, thinkers, scientists, and poets to refer to different concepts in various contexts (Tsur, 2003). In Keats's poetry, the term nothingness has been employed in the metaphorical rather than the literal sense. It has

Koya University Journal of Humanities and Social Sciences (KUJHSS),

Volume 3, Issue 1, 2020.

Received 12 June 2019; Accepted 21 June 2019, Regular research paper: Published 18 June 2020

Corresponding author's e-mail: yasir.jumaily@koyauniversity.org Copyright (C2020 Yasir A. Al-Jumaili. This is an open access article distributed under the Creative Commons Attribution License. always been featured negatively in many of his poems. Keats conceptualizes this term in different ways; it can be interpreted as a mental state or a "mystic mental process" that involves "self-abandonment and selfoblivion" (Tsur, 2003, pp. 72-73). The term "Nothingness" can also stand for states of existence, like the state of having never existed or a state of returning to nothingness after death (Tsur, 2003, p. 68). Nothingness can also be interpreted in terms of a location or a place. My argument in this paper is that Keats constructs nothingness as a hateful and undesired place which he does not want himself to be placed in. Keats mentions the term "nothingness" in four poems; I will focus on three poems as the denotative meaning refers to a place. I concentrate on the representation of nothingness as a physical location that is marked by certain negative qualities. I look at the language as evidence of how the poet chose to represent this abstract notion as a physical space. My interpretation is also context based; the representation of this state as a place is more enhanced when considered in relation to the contexts of the poems. 


\section{ANALYSIS}

In poetry, place refers not only to geographical locations but also natural environments. It sometimes extends to include locations of no physical existence such as mental places, abstract states, or even invisible landscapes (Fournier, 2010). In Mapping the Invisible Landscape: Folklore, Writing, and the Sense of Place (1993), Kent Ryden argues that a landscape does not become a "place" until it has acquired meaning in the mind of the speaker, through experience and use, or through stories of experiences from family and friends, overtime (Ryden, 1993, p. 115). In his poetry, Keats not only depicts places of physical existence but there are also places which are non-physically sensed. For instance, the fear of nothing as a destination dominates a good deal of his poetry; it is a recurrent theme in many of his poems. For example, in The Fall of Hyperion, Keats mentions spaces that "ending in mist of nothing" (Book I, L. 84). In Endymion, he mentions that his "sweet dream fell into nothing" (Book I, L. 678); or "a noisy nothing" that rings upon his ears (Endymion II, L. 321); and the feud "Twixt Nothing and Creation" (Book III, L. 41). In Calidore, he mentions "The widening circles into nothing gone" (L 18).

In his early poems, Keats describes nothingness as a place that is always associated with negativity. In these poems, Keats expresses fear and anxiety toward this place; even the thought of dwelling, there can fill his heart and mind with horror. The tone in these poems emits regret and lack of aspiration. "Nothingness" evokes many negative thoughts in the speaker's mind; it is the reflection of his inner feelings and apprehension. In general, he wants to capture the essence of this place; it is the absence of everything positive. Furthermore, whenever Keats mentions the term nothingness, a reference to poetry and art exists; poetry, fame, and love are in the center of his fears of nothingness. It is the speaker's major fear, and it always happens at the peak moment of the poem; in other words, it is the most hateful emotional experience of the poem. The way he speaks and represents nothingness in these poems sound like a hateful place that he is so familiar with.

In "Sleep and Poetry," Keats encounters nothingness for the $1_{\text {st }}$ time in his poetic career. The poem was written in 1816. It is Keats's early poetic manifesto, in which he shapes his poetic conceptions and expresses the superiority of poetry over other delightful things. The poem is subjective and written in personal mood; it records the speaker's conceptions about poesy that "should be a friend/To soothe the cares, and lift the thoughts of man" (II. 246-47). Since the poem is a call for inspiration, we see that the speaker is preoccupied with his imaginative experience. The poem, in general, is concerned with the poetic vision that enables the speaker to taste the beautiful realms he imagines.
The speaker introduces himself as a traveler who wanders in various realms. His vision catalogs a list of places which he creates through imagination. Among the locations, he depicts the place of nothingness. He visualizes this experience as "unpleasant muddy stream" that ends in the realms of nothingness:

The visions all are fled - the car is fled

Into the light of heaven, and in their stead

A sense of real things comes doubly strong,

And, like a muddy stream, would bear along

My soul to nothingness: but I will strive

Against all doubtings, and will keep alive

The thought of that same chariot, and the strange Journey it went (II. 155-162).

The passage pronounces Keats's most hateful moment in this poem. This moment marks the poem's dilemma; once imagination is hindered "a sense of real things comes doubly strong" to bear his soul to nothingness. As the speaker loses the beautiful visions, he begins experiencing the threat of nothingness. The representation of nothingness as a place is both linguistically and contextually proven. Linguistically speaking, the speaker uses metaphor of movement to represent nothingness as a place. The phrasal verb (bear along) is a combination of verb (bear) which means to "carry something from one place to another; or to cause to move by or with steady pressure" + the preposition (along) that means "moving in a constant direction on (a more or less horizontal surface)" (The Free Dictionary 2016; Oxford English Dictionary, 2018). The phrasal verb suggests moving toward a destination point. The destination point is also confirmed by the preposition "to" which precedes the word nothingness. The linguistic expression "bear along to" indicates a movement from one location to another. The image of "a muddy stream" also contributes to this metaphor; it suggests natural location that ends in a particular place. It serves as the vehicle that carries the speaker's soul from one location to another. It could stand for the path that leads the speaker to the undesired location (nothingness). Symbolically, the muddy stream represents reality whose end is nothingness, whereas the chariot and the steed represent the imagination whose end is the ideal and visionary world. Nothingness is the kingdom of sterility and unproductivity for those who are involved in the profession of writing such as poets. It recalls Keats's "spots of awfuller shade" (1. 76-77); it is where man becomes incapable of understanding "far from all men's knowing" (1.6) where everything becomes absurd and meaningless.

Contextually speaking, nothingness lies where the two elements - the inspiration and the imagination - which are very essential to the speaker are no longer exist. 
Early in this poem, speaker sets himself a goal of writing poetry that deals with human strife and agonies. However, writing poetry requires imagination; where there is no imagination, there is no poetry and where there is no poetry, there is nothingness. Therefore, the speaker experiences nothingness the moment he loses inspiration and imagination. The passage also contains an implied comparison between the places seen during the speaker's vision and the place described after the vision has fled. Nothingness comes as a post-visionary experience; it is associated with negative images of reality. The speaker sees nothing attractive in this location; therefore, he names it nothingness, it lacks the principle element in this universe (beauty). The place is marked by "all doubtings" that the speaker "will strive against." This means that nothingness is a place where nothing is certain; it is a circumference of uncertainty.

The second poem that mentions nothingness is "Endymion." The poem was written in 1817; it is Keats's first long poem which marks his first attempt to write an extended epic. The poem starts with a celebration of beauty. The poem opens with describes the source of Endymion's discontent with his life as a local chieftain.an implicit discontent with human nature and the idea of mortality. In this poem, Keats explores the relationship between the actual world experienced by human and the idealized world of human imagination. He emphasizes the sublime power of the idealized beauty which is not perishable (Nagarand and Prasad, 2005 , p. 192). He confirms that it is beauty that "moves away the pall/From our dark spirit" (11. 12-13).

As far as places are concerned, the poem contains descriptions of many natural locations and rustic scenes such as the quiet "bower" where the beauty can be experienced. It also depicts places that cause suffering and pain such as the "unhealthy" or "darkened ways" and "nothingness." Keats implicitly sets a comparison between the quiet bower that provides a sound sleep of sweet dreams whose eternal joy and attractiveness will never cease, and nothingness where everything becomes perishable. The bower provides shelter and protection, whereas nothingness offers cessation and termination:

A thing of beauty is a joy forever:

Its loveliness increases; it will never

Pass into nothingness; but still will keep

A bower quiet for us, (ll. 1-4)

In this passage, Keats uses nothingness to register his fears. Unlike things of beauty, his life will be terminated in the area of nothingness. The negation that beauty "will never pass into nothingness" implies that other things can or do. It is where beauty and joy are not experienced by him. In their article, "Poetry of the Invisible Landscape," Bill Siverly and Michael McDowell argued that "The more experiences a writer has had with a place, the more it may have acquired a spiritual and philosophical aspect for [him]" (Siverly and McDowell, NY, p. 37). Keats seems to be driven by this philosophical term. M. A. Goldberg discusses Keats's usage of the term nothingness in this poem. He argues that, although Keats's emphasis in Endymion is on the "thingfulness" of beauty; his usage of the word nothingness implies a lack of value rather than lack of substance (Goldberg, 1957, p. 49). This interpretation is mainly concerned with the term nothingness in its abstract sense. Nothingness can also be interpreted in terms of physicality; it can be taken as a reference to a physical location. The evidence is based on linguistic and contextual use of the metaphor "pass into nothingness." Linguistically, the use of the phrasal verb "pass into" suggests moving toward or in a specific direction According to Oxford Learner's Dictionary "pass into" is a phrasal verb which means "to enter or to become a part of something" (Oxford English Dictionary, 2018). Other dictionaries categorize "pass into" as an idiom which means "To move into something; to fade away into something" (The Free Dictionary 2016). Moreover, the combination of two prepositions of direction (in + to) signifies movement toward the interior of something; it also shows a completion of an action. In this sense, nothingness sounds like a physical location that things of beauty will not enter into or become part of; but other things do. It is the gist of the speaker's anxiety or a destination that he does not want to face.

Contextually, nothingness is a place where things cannot keep their beauty and loveliness forever. It is a place of oblivious qualities; where things which lack the value of beauty must perish. Since the lack of essence is a key point in this poem; therefore, nothingness is where things lose their essence and core (Hall, 2013). For Keats, the principle of beauty is of great importance; the opening lines explicitly state his philosophy that the core of this life is beauty. In a letter to Fanny Brawne, February 1820, Keats wrote, "I have loved the principle of beauty in all things" (Rollins, 1958, p. 263) (Keats to Fanny Brawne on February 1820). This offers a possible reading of the opening lines as where there is no beauty, there is nothingness; it is the antithesis of the world of beauty and joy. Again, the implicit discrepancy between the ideal and the real worlds is highly emphasized. It is in the ideal world that beauty never passes into nothingness, whereas in the real world, beauty is subject to decay.

Another poem that contains reference to nothingness is "When I have fears," it was written in 1818. It is a poem about melancholy and desperation; it can be considered as a personal confession of the current emotions that the speaker is experiencing. Instead of dispelling his fears in poetry, the speaker has found 
himself confirming and pronouncing them loudly. Although he is preoccupied with the idea of mortality, his fears in this poem are not mainly provoked by death. The speaker has clearly identified his fears; the last three lines of the poem pronounce the most dreaded one which is to sink into nothingness (Richards, 2010). Nothingness is introduced as a destination of failures and unsuccessful people. Keats has lived his short literary life with a permanent fear of being threatened by this idea. In a letter to Fanny Brawne, he declared his fears openly, "'If I should die,' Said I to myself, 'I have left no immortal work behind me - nothing to make my friends proud of my memory'" (Rollins, 1958, p. 263). (Keats to Fanny Brawne on February 1820). In this poem, the speaker mentions nothingness as the culmination of his fears and worries. The fear of nothingness is more horrible than "suffocating death" (Otho the Great, Act V, Scene II, 22); darker than "deepest gloom" (Endymion Book II, 629); and more dreadful than "the deep abyss" (Endymion Book II, 232).

It is Keats's most undesired destiny that being saved to the end of the poem to sum up all his fears which mentioned before. The three elements that preoccupy his mind (love, fame, and poetry) are all condemned to nothingness:

................ Then on the shore

Of the wide world I stand alone, and think

Till love and fame to nothingness do sink (II. 12-14).

Standing on the edge of the universe does not mean the end of it; there is still a place beyond this edge called nothingness. It is characterized by absolute void and emptiness where things fall and disappear forever. The image of standing alone on the shore of life and gazes at the nothingness where his ideals all diminish and disappear can be best understood in Nietzsche's words, "when you gaze for long into an abyss, the abyss also gazes into thee" (Nietzsche, 2004, Aphorism 146). Nothingness is the speaker's life abyss; as he gazes at it he finds it also gazing at him and this probably what causes his fears. This interpretation of nothingness as a place is supported by linguistic as well as contextual evidence. Linguistically, the verb "sink" means "to go down below the surface of something, or descend from a higher to a lower position" (Oxford English Dictionary, 2018). The language evidence indicates a direction or a destination point. Nothingness is metaphorically used to refer to a place where everything vanishes forever and never comes back again. It suggests falling into a bottomless place; the speaker knows that once he is placed there, he would be lost forever.

Contextually, nothingness is a place that challenges and threatens all the qualities of fruitful existence; all the speaker's aspirations, fulfillments, and achievements end there. The poem revolves around the speaker's failure to achieve love and fame within his short life. Nothingness is a place of isolation that challenges the poet's present and threatens his future. It even menaces his past; all past experiences lose their value in this place. It is where no effort can be made and no results can be seen, it is a complete vacuum where mind cannot conceive anything.

\section{CONCLUSION}

Just away from the world of natural beauty that has been described in his odes and the majestic places in his Hellenic works. A place of dreadful echoes has also been mentioned in his works, it is called nothingness. Its echoes are very loud and audible in many of his poems. Although the term is of abstract quality, it is also possible to be interpreted in terms of a physical space. It has been metaphorically represented, through language use and contextual reaching the speaker features some of its physical qualities. The speaker is not only worried about his soul traveling there but also even more worried that his poetry and fame could sink into this place. It has no center, no boundaries, or limits; he hates its Eerie Silence, emptiness, and its hollow existence.

\section{REFERENCES}

Fournier, J.M. (2010) Empty spaces and the poetics of silence in the poetry of John Keats. Études Anglaises, 63, pp. 88-98.

Goldberg, M.A. (1957) Keats' endymion, I, 1-35. Explicator, 25, p. 49.

Hall, J. (2013) Escapism, oblivion, and process in the poetry of Charlotte Smith and John Keats. Undergraduate honors theses. Available at: https://www.dc.etsu. edu/honors/62. . (Accessed: 20 May 2019).

Nagarand, A. and Prasad, N.A. (2005) Recritiquing John Keats: Compilationn of studied research papers and articles on Keats. New Delhi: Sarup and Sons.

Nietzsche, F. (2004) Beyond good and evil, Part IV-Aphorism 146. Iowa: 1st World Publishing.

Oxford English Dictionary. (2018) Available at: http://www.oed.com. (Accessed: 18 May 2018).

Richards, B. (2010) Analysis of John Keats's 'when i have fears: Death and the freedom of limitations. Inquiries Journal/Student Pulse, 2(11). Available from: http://www.inquiriesjournal.com/a?id=316. (Accessed: 27 April 2019).

Rollins, H.E. (1958) The letters of John Keats. Vol. 2. Cambridge: Cambridge University Press, pp. 1819-1821, 1814-1821.

Ryden, C.K. (1993) Mapping the invisible landscape: Folklore, writing, and the sense of place. Iowa City: University of Iowa Press.

Siverly, B. and McDowell, M. Poetry of the Invisible Landscape. Available at: http://www.hevanet.com/windfall/wf21/wf21_afterword.pdf. (Accessed: 2019 April 15).

Tsur, R. (2003) On the shore of nothingness: Space, rhythm, and semantic structure in religious poetry and its mystic-secular counterpart: A study in cognitive poetics. Exeter: Imprint Academic, pp. 72-73. 